\title{
The lag structure of the impact of business ownership on economic performance in OECD countries
}

Citation for published version (APA):

Carree, M. A., \& Thurik, A. R. (2008). The lag structure of the impact of business ownership on economic performance in OECD countries. Small Business Economics, 30(1), 101-110. https://doi.org/10.1007/s11187-006-9007-0

Document status and date:

Published: 01/01/2008

DOI:

10.1007/s11187-006-9007-0

Document Version:

Publisher's PDF, also known as Version of record

\section{Please check the document version of this publication:}

- A submitted manuscript is the version of the article upon submission and before peer-review. There can be important differences between the submitted version and the official published version of record.

People interested in the research are advised to contact the author for the final version of the publication, or visit the DOI to the publisher's website.

- The final author version and the galley proof are versions of the publication after peer review.

- The final published version features the final layout of the paper including the volume, issue and page numbers.

Link to publication

\footnotetext{
General rights rights.

- You may freely distribute the URL identifying the publication in the public portal. please follow below link for the End User Agreement:

www.umlib.nl/taverne-license

Take down policy

If you believe that this document breaches copyright please contact us at:

repository@maastrichtuniversity.nl

providing details and we will investigate your claim.
}

Copyright and moral rights for the publications made accessible in the public portal are retained by the authors and/or other copyright owners and it is a condition of accessing publications that users recognise and abide by the legal requirements associated with these

- Users may download and print one copy of any publication from the public portal for the purpose of private study or research.

- You may not further distribute the material or use it for any profit-making activity or commercial gain

If the publication is distributed under the terms of Article $25 \mathrm{fa}$ of the Dutch Copyright Act, indicated by the "Taverne" license above, 


\section{The Lag Structure of the Impact of Business Ownership on Economic Performance in OECD Countries}

\begin{abstract}
This paper investigates the impact of changes in the number of business owners on three measures of economic performance, viz. employment growth, GDP growth and labor productivity growth. Particular attention is devoted to the lag structure. The analysis is performed at the country level for 21 OECD countries. Our results confirm earlier evidence on three stages in the impact of entry on economic performance: an initial direct positive effect, followed by a negative effect due to exiting capacities and finally a stage of positive supply-side effects. The net effect is positive for employment and GDP growth. Changes in the number of business owners have no effect on labor productivity.
\end{abstract}

KEYWORDS: business ownership, entrepreneurship, economic growth, lag structure

JEL CLASSIFICATIONS: L26, M13, O40

\section{Introduction}

The impact of entrepreneurship on economic performance is receiving increased attention in both the empirical and theoretical economics literature. Recent regional analyses like Acs and Armington (2004) using U.S. data, Audretsch and Keilbach (2004) using German data, Foelster (2000) using Swedish data and van Stel and

Final version accepted on August 2006.

M.A. Carree

Faculty of Economics and Business Administration

University of Maastricht

P.O. Box 616, Maastricht, 6200 MD,

The Netherlands

A.R. Thurik

Centre for Advanced Small Business Economics (CASBEC)

Erasmus University Rotterdam

P.O. Box 1738, Rotterdam, 3000 DR,

And EIM, P.O. Box 7001, Zoetermeer, 2701 AA,

The Netherlands

E-mail:thurik@few.eur.nl
Storey (2004) using U.K. data, find a positive effect of start-ups on growth. However, there is also evidence that this effect may not be constant over time. Van Stel and Storey (2004) find that there was a positive impact in the U.K. in the 1990s whereas this was absent in the 1980s. A similar result was found in the studies by Audretsch and Fritsch $(1996,2002)$ for German regions. The effects of entrepreneurial activity may also differ during the different stages of the development path of economies. Van Stel et al. (2005) suggest that the positive impact of entrepreneurial activity may not be present in lesser developed countries.

Targeted assistance to small and young businesses is often proposed when fostering growth and economic development (Johnson, 2005). This is not only the case for developing economies ${ }^{1}$ but also for the member states of the European Union. ${ }^{2}$ Europe suffers from a period of stagnant economic growth and persistently high levels of unemployment. On the one hand, politicians turn to promoting entrepreneurship and since it is assumed that the sector of small and young businesses is one where entrepreneurship thrives they embrace targeted assistance here. ${ }^{3}$ On the other hand, they are also concerned about the productivity performance of Europe. ${ }^{4}$ Small and young firms often underperform in this respect as many operate below the minimum efficient scale and show relatively low survival rates (Taymaz, 2005). The examination of the role of small and medium sized businesses as a determinant of economic performance is an obvious response since there may be a trade-off between their roles accelerating and hampering performance.

Fritsch and Mueller (2004) made an important contribution by showing that there may be both positive and negative effects of new firm 
formation on regional employment change, occurring with different time lags. It is obvious that there may be important lags between changes in the composition of the small business sector and economic performance because the processes of selection and of learning about what consumers prefer, what is technologically viable and how to obtain the necessary resources, take considerable time. Fritsch and Mueller (2004) have provided us with a clear picture of this lag structure. They distinguish between three stages. The first stage is one of the direct positive employment effect of new capacities. The impact is due to start-ups in the current year creating additional jobs at the time of inception. The second stage is one of exiting capacities, due to the infant mortality of start-ups and the crowding-out of incumbents. Hence, this stage is characterized by a negative impact on employment growth. The last stage is the stage in which the start-ups again contribute to employment by direct or indirect supply-side effects. In the longer term the successful new firms promote increased efficiency due to intensified competition and process innovation and enhance market demand due to product innovation leading to a greater variety of products and hence to a better correspondence to the diversity of consumer preferences. Fritsch and Mueller find that the peak of the negative impact and that of the positive impact occur at about three to four years and six to seven years after start-up, respectively.

Increased understanding of the lag structure of the impact of new firm formation at the same time will guide us towards a better understanding of the various effects of new firms on economic performance of regions, industries and countries. The present study examines the lag structure of the impact of changes in the number of business owners on three measures of economic performance, viz. employment growth, GDP growth and labor productivity growth. The model is estimated both with and without lagged endogenous variables and both with and without country fixed effects. Moreover, possible problems connected with multicollinearity are overcome by using the growth rates instead of the actual values of the logarithms of all variables. The analysis is performed at the country level for 21 OECD countries. ${ }^{5}$ Section 2 provides a further discussion of the effect of business ownership on economic growth. Section 3 describes the data and the method. Section 4 contains the estimation results and Section 5 concludes.

\section{Business ownership and economic performance}

The many ways in which business owners (entrepreneurs) may be instrumental for economic growth are dealt with in Carree and Thurik (2003). In fact, there are several intermediary processes. Entrepreneurs may introduce important innovations by entering markets with newly developed products or production processes (Acs and Audretsch, 1990, 2003). They may increase productivity because they increase competition by their sheer number (Geroski, 1989; Glaeser et al., 1992; Nickell, 1996; Nickell et al., 1997). The introduction of variations of existing products and services to the market leads to a more adequate understanding of consumer preferences and of what is technically viable. In earlier stages of the life cycle this can speed up the arrival of the dominant design for product-market combinations. The spillover of knowledge between market participants plays an important role in this process (Audretsch and Feldman, 1996; Audretsch and Stephan, 1996; Audretsch and Keilbach, 2003). Lastly, entrepreneurs tend to work longer hours than employees since their income is directly linked to their working effort. ${ }^{6}$

Many of the abovementioned supply-side effects may only become apparent in the long term. What will happen in the short term? The three stages of Fritsch and Mueller (2004) typically unfold as follows. Initially the entry of new firms will leave employment and production capacity of incumbent firms unaltered. Hence, employment may rise with the number of new business owners and their newly hired personnel. The increase in production capacity will lead to both new and incumbent firms making losses. There are likely to be three market reactions in the years directly after the entry of new firms. First, there will be exit of newly entered and incumbent firms. This is a result of the relatively high hazard rates of young firms (e.g. Evans, 1987; Storey and Wynarczyk, 1996) and 
of displacement effects (e.g. de Backer and Sleuwaegen, 2003 and Lay, 2003). This will eliminate part of the initial employment gains. Second, the surviving young firms and incumbents will pursue product and process innovation to improve upon their market position. The results of these investments will emerge in the third stage. Third, incumbent firms will seek to cut costs by lowering employment. Total employment may or may not decrease as a result of labor saving. ${ }^{7}$ In the third stage the economy turns out to be more competitive due to improved production processes and improved products resulting from the selection and innovation that took place in the second stage. ${ }^{8}$ In this stage the surviving entrants may contribute considerably to the economy ('gazelles') and also the surviving incumbents will be more competitive than beforehand.

Fritsch and Mueller (2004) investigated the lag structure at the regional level for West German districts. Our present study analyses whether a similar lag structure can be found at the country level. The only variable available to measure entrepreneurship at the country level for a long time period is the number of businesses or the number of business owners. Alternatives like the GEM Total Entrepreneurial Activity rate measuring the relative amount of nascent entrepreneurs and business owners of young firms (see van Stel et al., 2005) and entry and exit rates (see Bartelsman et al., 2003) do not have the required length of time series. Hence, it is also not possible to investigate the effects of turbulence (entry plus exit) on economic performance at the country level. ${ }^{9}$ Papers that have used the business ownership rate as an indicator of entrepreneurship include Carree et al. (2002) and Audretsch et al. (2005).

A related measure to the business ownership rate is the share of small businesses. Carree and Thurik (1999) indicate that the presence of small businesses in manufacturing industries benefits growth for the richest among EU-countries, but not for EU-countries with somewhat lower GDP per capita, like Portugal and Spain. Van Stel et al. (2005) provide additional evidence that small and young businesses are more important in later stages of economic development. This is in line with the regime shift from a model of the 'managed economy' towards that of the 'entrepreneurial economy' introduced by Audretsch and Thurik (2001). Under the model of the 'entrepreneurial economy' the more traditional production factors such as land, labor and capital are not just supplemented by the production factor of knowledge but also by a very different, but complementary factor: entrepreneurship capital, or the capacity to engage in and generate entrepreneurial activity. Beck et al. (2005) find for a data set of 45 countries a strong positive association between the presence of SMEs and GDP per capita growth, although the direction of causality remains unclear. Robbins et al. (2000) find that U.S. states with a higher proportion of small business employment experienced a higher level of productivity and Gross State Product growth.

These country studies suffer from two major shortcomings. First, the lag-structure of the effect of new business formation as found by Fritsch and Mueller (2004) and van Stel and Storey (2004) is not taken into account. Both studies indicate that any additional effect of new firm formation on regional employment fades out after ten years. Second, there is the paradox of the assumed low productivity of small businesses - often operating below the minimum efficient scale - and their alleged positive contribution to economic growth. The present analysis attempts to address these two shortcomings. It is important not only to consider the contribution of small businesses to employment growth, but also to changes in average labor productivity. The data come from the COMPENDIA dataset (van Stel, 2005). ${ }^{10}$ Economic performance is measured in employment, GDP and labor productivity growth so that the paradox of low productivity and contribution to economic growth can be given attention.

\section{Method}

We introduce a simple model in line with some earlier work about the influence of entrepreneurship measures on economic development like van Stel et al. (2005) and Audretsch et al. (2005). The model relates the (logarithmic) change of employment, GDP or labor productivity to the (logarithmic) change of the 
number of business owners. We use different lag structures with the number of lags for the change in the endogenous variable and for business ownership assumed to be equal (to $L$ ). Denoting by $Y$ the logarithm of employment or GDP or labor productivity and that of business owners by $B O$, the model reads as

$$
\begin{aligned}
Y_{i t}-Y_{i, t-2}= & +\sum_{k=0}^{L} \alpha_{k}\left(\mathrm{BO}_{i, t-2 k}-\mathrm{BO}_{i, t-2(k+1)}\right) \\
& +\sum_{k=1}^{L} \beta_{k}\left(Y_{i, t-2 k}-Y_{i, t-2(k+1)}\right)+\varepsilon_{i t}
\end{aligned}
$$

Note that we allow the impact of changes in business ownership to have an immediate effect. The value of $\alpha_{0}$ can be used to determine the direct effect of new capacities. However, we will also present results where this immediate impact is left out of the model. The lagged change in growth of the economic performance measure is incorporated in the model to attempt to correct for reversed causality in a Granger fashion. ${ }^{11}$ Since model (1) only contains growth rates, multicollinearity problems are not to be expected. The fact that we work with two-year periods is a consequence of using the harmonized COMPENDIA dataset (van Stel, 2005). However, such periods are adequate for identifying the lag structure as brought forward by Fritsch and Mueller. The framework obviously differs from theirs since we consider the impact of the net relative change in the number of self-employed instead of a gross entry measure.

Equation (1) does not directly consider unobserved heterogeneity across countries. Although our model is in first differences, there may be unobserved fixed country-specific effects. Incorporating such effects into equation (1) would result in a dynamic panel data model with $L$ lagged endogenous variables, introducing important complications for estimation (see e.g. Hsiao, 2003, chapter 4), especially given the relatively limited sample size. However, we may incorporate fixed effects $\left(\gamma_{\mathrm{i}}\right)$ in stead of the lagged endogenous variables to evaluate potential problems of unobserved heterogeneity:

$$
\begin{aligned}
Y_{i t}-Y_{i, t-2} & =\gamma_{i}+\sum_{k=0}^{L} \alpha_{k}\left(\mathrm{BO}_{i, t-2 k}-\mathrm{BO}_{i, t-2(k+1)}\right) \\
& +\varepsilon_{i t}
\end{aligned}
$$

The COMPENDIA (COMParative Entrepreneurship Data for International Analysis) data set contains two-yearly data for OECD countries for the period 1972-2002. We exclude two small countries, Iceland and Luxembourg. We do so because of the specialized nature of their economies (fishery for Iceland and banking for Luxembourg) and because they would contribute disproportionally in our unweighted setup. Changes in the number of business owners, as well as GDP growth, employment growth and labor productivity growth are calculated as percentage change from year to year, starting in 1974. This calculation is made for all (even) years, through 2002, which leaves us with 15 years of observation. Labor productivity at the country level is in the current paper defined as GDP divided by employment. Percentage changes for these variables for the entire thirty year period are given in Table I for 21 OECD countries. The average business ownership rate (as a percentage of labor force) in OECD countries has increased slowly over the thirtyyear period, from $9.9 \%$ in 1972 to $11.0 \%$ in 2002. However, this average masks a substantial variety in the development of the business ownership rate across countries. The three countries with the strongest increase in this percentage were Canada (from $7.9 \%$ in 1972 to $12.2 \%$ in 2002), Italy (from $14.3 \%$ to $18.3 \%$ ) and Australia (from $12.6 \%$ to $16.4 \%$ ). The three countries with the strongest decrease were Japan (from $12.5 \%$ to $9.2 \%$ ), France (from $11.3 \%$ to $8.1 \%$ ) and Norway (from $9.7 \%$ to $6.5 \%$ ).

The correlations of the exogenous variables, being (logarithmic) changes of business ownership, are relatively low, as can be seen from Table II. Hence, there are no concerns of multicollinearity. The correlation of the (logarithmic) change of employment, $E_{i t}-E_{i, t-2}$, is highest with the current change of business ownership, $B O_{i t}-B O_{i, t-2}$, directly followed by that of the change a decade beforehand, $B O_{i, t-10}-B O_{i, t-12}$. There is one negative corre- 
TABLE I

Average two-year percentage growth rates in the number of business owners (BO), GDP, employment (EMP) and labor productivity (LP), 1972-2002

\begin{tabular}{lrrrr}
\hline & $\Delta$ BO & $\Delta$ GDP & $\Delta$ EMP & $\Delta$ LP \\
\hline France & -0.7 & 4.7 & 0.9 & 3.6 \\
Norway & -0.2 & 6.6 & 2.3 & 4.3 \\
Japan & -0.2 & 5.7 & 1.3 & 4.2 \\
Denmark & -0.1 & 4.3 & 0.9 & 3.3 \\
Austria & 1.2 & 4.8 & 1.7 & 3.0 \\
Sweden & 1.3 & 3.7 & 0.5 & 3.2 \\
Belgium & 1.7 & 4.5 & 0.7 & 3.7 \\
Germany & 1.9 & 4.1 & 0.5 & 3.6 \\
Switzerland & 2.1 & 2.5 & 0.7 & 1.8 \\
Finland & 2.6 & 5.6 & 0.7 & 4.6 \\
Spain & 2.9 & 5.6 & 1.7 & 4.0 \\
The Netherlands & 2.9 & 4.9 & 2.3 & 2.5 \\
Italy & 3.2 & 4.9 & 1.1 & 3.7 \\
United Kingdom & 3.3 & 4.3 & 1.3 & 3.1 \\
Greece & 3.4 & 5.3 & 1.6 & 3.7 \\
Portugal & 4.1 & 5.9 & 2.5 & 3.3 \\
New Zealand & 4.7 & 4.5 & 2.7 & 2.0 \\
USA & 4.7 & 5.5 & 3.3 & 2.1 \\
Australia & 5.5 & 6.6 & 3.4 & 3.1 \\
Ireland & 6.1 & 11.3 & 3.6 & 7.3 \\
Canada & 7.5 & 6.3 & 4.1 & 2.3 \\
Average & 2.8 & 5.3 & 1.8 & 3.4 \\
\hline Source: COMPENDIA & 2002.1 & & &
\end{tabular}

Source: COMPENDIA 2002.1.

lation for the employment change, i.e. with $B O_{i, t-4}-B O_{i, t-6}$.

\section{Empirical results}

The estimation results of models (1) and (2) explaining employment growth can be found in Table III. We first concentrate on the employ- ment growth results since they were also the focus of the Fritsch and Mueller (2004) article. In the first four columns of Table III - (1a) through $(2 b)$ - results are shown for $L$ equal to seven. This implies that an impact after 14 years is allowed for. The results indicate that after ten years there is no significant impact anymore. Therefore, we present the results for $L$ equal to five in the last four columns of Table III - (1c) through $(2 \mathrm{~d})$. The results are presented both with and without direct effects - columns (1a), (2a), (1c) and (2c) versus columns (1b), (2b), (1d) and (2d) - and for model (1) with lagged endogenous variables and model (2) with fixed effects - columns (1a) through (1d) versus columns (2a) through (2d). We have added the results when excluding the immediate impact of change of business ownership, $\alpha_{0}=0$, since the direction of causality may be unclear. See columns (1b), (2b), (1d) and (2d).

The results provide clear confirmation of those found by Fritsch and Mueller (2004) for West Germany. However, where Fritsch and Mueller use (gross) measures of new firm formation the present paper uses (net) changes in the number of new businesses, where Fritsch and Mueller use regional data the present paper uses country data and where Fritsch and Mueller use only employment data the present paper reports on other performance measures as well. The former difference in particular leads to slight differences in interpretation of the results. For interpreting the direct employment effect, it should be noted that business owners are also considered as (self-)employed. An increase of

TABLE II

Correlation matrix of two-year growth rates of the number business owners (BO) and employment (EMP)

\begin{tabular}{|c|c|c|c|c|c|c|c|c|c|}
\hline Variable & $\Delta \mathrm{EMP}_{t}$ & $\Delta \mathrm{BO}_{t}$ & $\Delta \mathrm{BO}_{t-2}$ & $\Delta \mathrm{BO}_{t-4}$ & $\Delta \mathrm{BO}_{t-6}$ & $\Delta \mathrm{BO}_{t-8}$ & $\Delta \mathrm{BO}_{t-10}$ & $\Delta \mathrm{BO}_{t-12}$ & $\Delta \mathrm{BO}_{t-14}$ \\
\hline $\mathrm{EMP}_{t}-\mathrm{EMP}_{t-2}$ & 1 & & & & & & & & \\
\hline $\mathrm{BO}_{t}-\mathrm{BO}_{t-2}$ & 0.32 & 1 & & & & & & & \\
\hline $\mathrm{BO}_{t-2}-\mathrm{BO}_{t-4}$ & 0.12 & 0.24 & 1 & & & & & & \\
\hline $\mathrm{BO}_{t-4}-\mathrm{BO}_{t-6}$ & -0.07 & 0.13 & 0.23 & 1 & & & & & \\
\hline $\mathrm{BO}_{t-6}-\mathrm{BO}_{t-8}$ & 0.05 & 0.04 & 0.15 & 0.26 & 1 & & & & \\
\hline $\mathrm{BO}_{t-8}-\mathrm{BO}_{t-10}$ & 0.15 & 0.07 & 0.08 & 0.17 & 0.24 & 1 & & & \\
\hline $\mathrm{BO}_{t-10}-\mathrm{BO}_{t-12}$ & 0.28 & 0.17 & 0.10 & 0.07 & 0.11 & 0.26 & 1 & & \\
\hline $\mathrm{BO}_{t-12}-\mathrm{BO}_{t-14}$ & 0.14 & 0.04 & 0.16 & 0.06 & 0.10 & 0.15 & 0.31 & 1 & \\
\hline $\mathrm{BO}_{t-14}-\mathrm{BO}_{t-16}$ & 0.02 & 0.04 & 0.06 & 0.19 & 0.12 & 0.14 & 0.19 & 0.43 & 1 \\
\hline
\end{tabular}

Source: COMPENDIA 2002.1.

Note: $\Delta \mathrm{EMP}_{t}=\mathrm{EMP}_{t}-\mathrm{EMP}_{t-2}$, etc. 


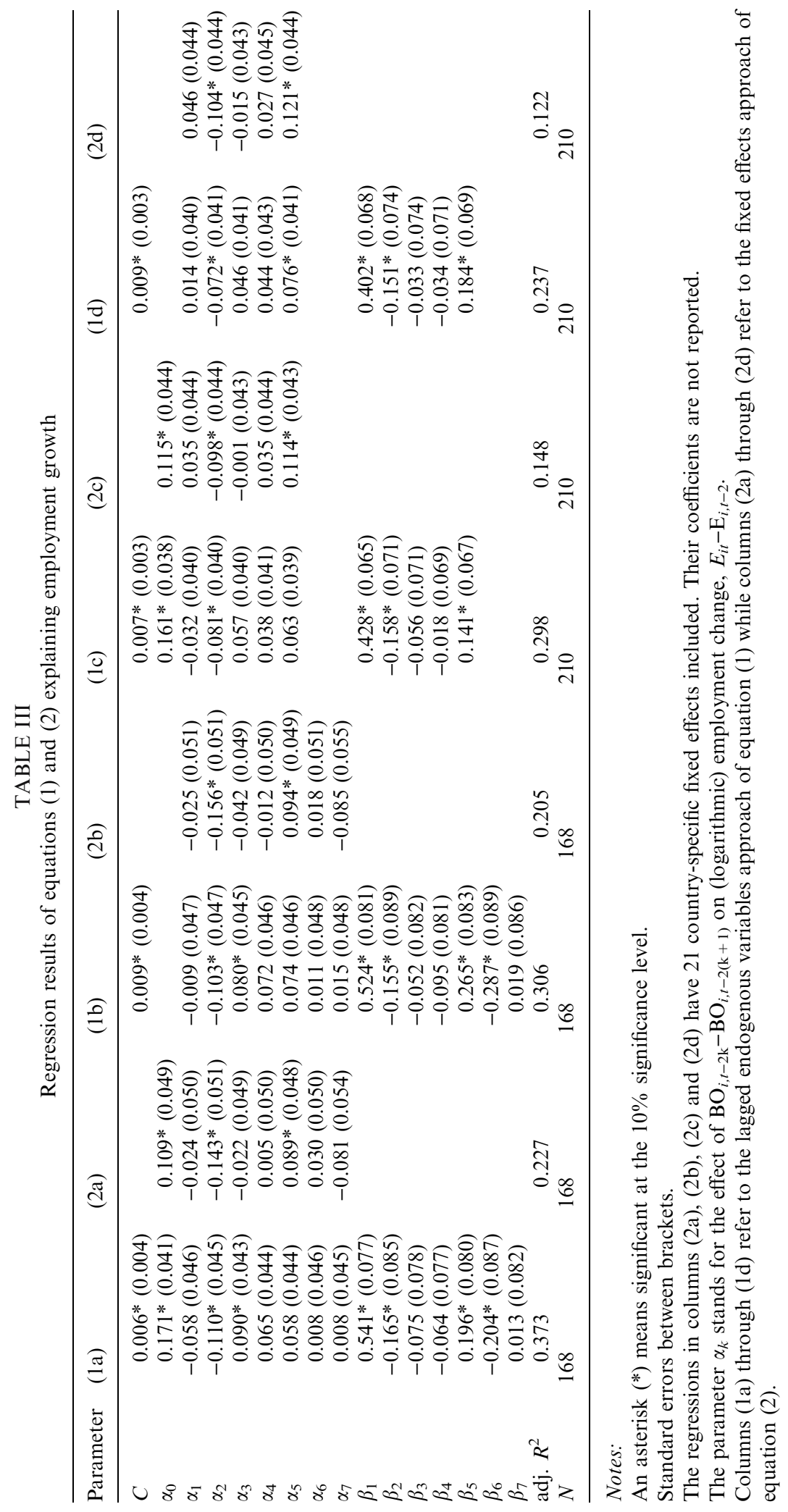


$1 \%$ in the number of business owners in a country therefore directly results in a $\mathrm{K} \%$ increase in total employment when the business owners represent $100 \mathrm{~K} \%$ of employment. However, see van Stel and Storey (2004) where a negative impact is reported for regions where numerous new firms are subsidized. Also in the present paper the effect is unlikely to be negative.

First, the effects appear to die out after ten years. This also confirms results found by Mueller et al. (2007) for U.K. regions. Second, there is a strong direct positive employment effect by creating new capacity. ${ }^{12}$ The coefficient of 0.17 indicates that, since the average OECD business ownership rate is about $11 \%$, employment rises not only due to more business owners but also due to new personnel being hired. Third, in the first four years after the change in business ownership there is a negative impact on employment change with a clear peak in the third and fourth year, identical to the years found by Fritsch and Mueller. Apparently, this is a phase of exiting capacities. Fourth, in the six years thereafter, the impact on employment change reverses and becomes positive. It may take several years before the effects of increased innovation and market selection start to pay off. Models (1) and (2) tend to differ with respect to the period in which the positive effect becomes clearly visible: for model (2) it is later. The adjusted $R$-squared indicate that the model specification (1) should be preferred to that of model specification (2).

The results for GDP growth and labor productivity growth are presented in Table IV. We only display the results for model (1) since the fit (adjusted $R$-squared) was superior to that of the fixed effects model (2). Columns (1a) and (1b) refer to GDP growth and columns (1c) and (1d) to labor productivity growth. Results without direct effect $\left(\alpha_{0}=0\right)$ are not reported. Again for GDP growth there is a strong immediate impact. The second two stages of exiting capacities followed by positive supply-side impacts in the succeeding years can be detected in the results but fail to show significance. Business ownership growth appears to have no negative effects on labor productivity

TABLE IV

Regression results using equation (1) for GDP growth (columns 1a and 1b) and labor productivity growth (columns 1c and 1d)

\begin{tabular}{|c|c|c|c|c|}
\hline Parameter & (1a) & (1b) & (1c) & (1d) \\
\hline$c$ & $0.001(0.009)$ & $0.014 *(0.007)$ & $0.007(0.006)$ & $0.011 *(0.005)$ \\
\hline$\alpha_{0}$ & $0.162 *(0.052)$ & $0.193 *(0.046)$ & $0.031(0.039)$ & $0.065 *(0.037)$ \\
\hline$\alpha_{1}$ & $-0.057(0.056)$ & $-0.065(0.048)$ & $-0.022(0.041)$ & $-0.036(0.038)$ \\
\hline$\alpha_{2}$ & $-0.020(0.056)$ & $-0.022(0.048)$ & $0.068(0.042)$ & $0.059(0.038)$ \\
\hline$\alpha_{3}$ & $0.049(0.053)$ & $0.039(0.048)$ & $-0.013(0.040)$ & $-0.001(0.037)$ \\
\hline$\alpha_{4}$ & $0.041(0.055)$ & $0.005(0.050)$ & $-0.023(0.041)$ & $-0.019(0.038)$ \\
\hline$\alpha_{5}$ & $0.073(0.054)$ & $0.042(0.047)$ & $0.031(0.040)$ & $0.009(0.036)$ \\
\hline$\alpha_{6}$ & $-0.092(0.056)$ & & $-0.064(0.042)$ & \\
\hline$\alpha_{7}$ & $-0.015(0.055)$ & & $0.019(0.041)$ & \\
\hline$\beta_{1}$ & $0.569 *(0.080)$ & $0.441 *(0.065)$ & $0.151 *(0.082)$ & $0.067(0.065)$ \\
\hline$\beta_{2}$ & $-0.151 *(0.089)$ & $-0.105(0.070)$ & $0.040(0.078)$ & $0.039(0.064)$ \\
\hline$\beta_{3}$ & $0.056(90.080)$ & $0.016(0.069)$ & $0.131 *(0.069)$ & $0.116^{*}(0.062)$ \\
\hline$\beta_{4}$ & $0.025(0.080)$ & $0.076(0.068)$ & $0.032(0.068)$ & $0.055(0.061)$ \\
\hline$\beta_{5}$ & $0.329 *(0.080)$ & $0.225^{*}(0.064)$ & $0.284 *(0.069)$ & $0.277 *(0.061)$ \\
\hline$\beta_{6}$ & $-0.031(0.085)$ & & $0.071(0.069)$ & \\
\hline$\beta_{7}$ & $0.106(0.076)$ & & $0.015(0.068)$ & \\
\hline adj. $R^{2}$ & 0.393 & 0.310 & 0.135 & 0.107 \\
\hline $\mathrm{N}$ & 168 & 210 & 168 & 210 \\
\hline
\end{tabular}

Notes:

An asterisk (*) means significant at the $10 \%$ significance level.

Standard errors between brackets.

The parameter $\alpha_{k}$ stands for the effect of $\mathrm{BO}_{i, t-2 \mathrm{k}}-\mathrm{BO}_{i, t-2(\mathrm{k}+1)}$ on $\mathrm{Y}_{i t}-\mathrm{Y}_{i, t-2}$, where $\mathrm{Y}$ is the logarithm of GDP in columns (1a) and (1b) and the logarithm of labor productivity (GDP divided by employment) in columns (1c) and (1d). 
growth. Hence, concerns about the entry of new firms leading to an underperformance in terms of productivity appear unwarranted. Apparently, the start-up of new firms ${ }^{13}$ leads to an immediate short-term positive effect because of attracting new employees and capital investments. However, after some years a fair share of the new firms exits again, with negative impacts on employment but less so on economic growth. This latter effect may be due to some efficiency gains (the value of $\alpha_{2}$ for labor productivity growth is positive although not significant). However, there is a third effect: that of the surviving firms that start to really contribute to economic growth. They may start hiring their first employees or may even be the fastgrowing 'gazelles', responsible for a substantial share of newly created jobs.

\section{Conclusion}

The relation between the number of business owners and economic growth is not straightforward. There is dual causality (Audretsch et al., 2005), measurement problems (Wennekers and Thurik, 1999), sectoral issues and an alleged complex lag structure (Fritsch and Mueller, 2004).

In this paper we have investigated the lag structure of the impact of business ownership on three measures of economic performance using country level data. The well documented long term positive effects of new firm formation (brought about by combinations of understanding technical newness and consumer preferences, of increased competition, of spillovers and learning and of other entrepreneurial forces like the long working hours of business owners) may not arrive immediately and monotonously. The lag structure of the impact of the change in the number of business owners on employment change appears to follow the pattern as described in Fritsch and Mueller (2004) and to consist of three stages (a direct positive one followed by a negative and a positive stage). Where Fritsch and Mueller use measures of new firm formation the present paper uses changes in the number of new businesses. The results are remarkably similar despite this difference in the way the pivotal variable is constructed. An implication might be that the effect of firm exits
- the difference between gross and net entry - on the performance measures is not immediate. The cumulative positive employment effect of the entry of new businesses may take at least five years to emerge. This is an important signal for setting up and interpreting effect studies of policy measures promoting new firm entry and, more importantly, its performance effect on the entire industry, region or country. Eliasson (1995) even claimed that it may take up to two decades to see performance differences between economies with or without new entry.

Our results show that for GDP growth there is a strong immediate impact whereas the succeeding two stages of exiting capacities followed by positive supply-side impacts can be detected indeed but fail to show significance. Our results also show that there is no evidence for a cumulative negative effect on productivity. This negative effect is sometimes brought forward in the face of the low productivity of young, small businesses operating below the minimum efficient scale. They do so expecting to have an option of future scale and productivity growth. Additional research into the distribution of time lags for different countries and in different industries may provide further support for the three-stage model of the impact of new firm formation.

\section{Acknowledgements}

Assistance of André van Stel and Viktor Stunnenberg (Erasmus University Rotterdam and Max Planck Institute, Jena) and comments by Rob van der Horst (EIM Business and Policy Research, Zoetermeer), Michael Fritsch (Technische Universiät Freiberg) and two anonymous referees are gratefully acknowledged. The paper has been written in the framework of the research program SCALES carried out by EIM Business and Policy Research in Zoetermeer and financed by the Dutch Ministry of Economic Affairs.

\section{Notes}

\footnotetext{
1 See Beck et al. (2005).

2 See the various editions of the European Observatory for SMEs, submitted to the Enterprise Directorate of the European Commission. See also European Commission (1999 and 2004).
} 
3 Entrepreneurship and small business are related but not synonymous concepts. On the one hand, entrepreneurship is a type of behavior concentrating on opportunities rather than resources (Stevenson and Gumpert, 1991). This behavior may be present in both small and large businesses. On the other hand, the small business sector with its large number of businesses can be a vehicle for both Schumpeterian entrepreneurs introducing new products and processes and for people who simply run and own a business for a living (Kirchhoff, 1994; Wennekers and Thurik, 1999). Where entrepreneurship and small businesses overlap is in the area of small, young and often fast growing businesses. 4 The European Commission's 2003 Competitiveness Report states (page 10 in the executive summary) that 'The natural limits to long run increases in employment rates together with the increased weight of less skilled/lower productivity workers inherent to increases in the overall employment rate (at least in the short run), bring labor productivity developments to the centre stage of a sustainable long-term improvement in living standards. Despite the modest narrowing of the EU gap in standards of living in the period 2001-2002, the fact remains that sustainable longterm increase in living standards and convergence towards US levels will require a strong improvement in the productivity performance of the EU.'

5 Other studies use regions within one country as the unit of observation and deal with gross entry measures rather than net entry. See Fritsch (2007).

6 See Carree and Thurik (2003) and Audretsch and Thurik (2001) for a more elaborate treatment of the intervening variables between entrepreneurship and growth. See also Acs and Audretsch (2003) and Audretsch and Thurik (2003).

7 A simple model of $N$ equally sized firms in a perfectly competitive market can be used to illustrate this. Assume a linear total demand function $Q=A-B p$, no fixed costs and unit cost of production equal to wage $(w)$ times units of labor needed $(l)$. Perfect competition implies no profit, or $p=w l$. From this total production is directly derived as $Q=A-w B l$ and total employment as $A l-w B l^{2}$. For values of $l$ higher than $A$ / $2 w B$ total employment will increase when there is labor saving, whereas it will decrease for values of $l$ lower than $A / 2 w B$.

8 Carree (2002) reports empirical evidence for France, Germany, Japan, U.K. and U.S. that manufacturing industries that experienced little downsizing in the 19771990 period showed less subsequent growth when compared internationally.

9 Reynolds (1999) presents evidence using US Labor Market Area data that turbulence is positively related to economic growth.

10 All variables are computed for the entire economy with the exception of the business ownership rate which excludes the primary sectors of production.

11 The Granger (1969) approach to the question of whether $x$ causes $y$ is to see how much of the current $y$ can be explained by past values of $y$ and then to see whether adding lagged values of $x$ can improve the explanation. $y$ is said to be Granger-caused by $x$ if $x$ helps in the prediction of $y$, or equivalently if the coefficients on the lagged $x$ 's are statistically significant.
12 The highly significant coefficient for $\alpha_{0}$ may indicate that changes in business ownership have a direct positive effect on employment growth. They may also indicate the reverse: that in periods of economic growth more firms are being started up and less exit. Data at the country level are too aggregated to discriminate between these two effects. Probably both views are true to some extent. See also van Stel and Suddle (2007) for an empirical exercise investigating the direction of causality for the immediate effect.

13 A positive value of $\Delta \mathrm{BO}$ - being a net entry measure as opposed to the gross entry measures of the regional studies - implies that entry is in access of exit.

\section{References}

Acs, Z. J. and C. Armington, 2004, 'Employment Growth and Entrepreneurial Activity in Cities', Regional Studies 38, 911927.

Acs, Z. J. and D. B. Audretsch, 2003, 'Innovation and Technological Change', in Z. J. Acs and D. B. Audretsch (eds.), Handbook of Entrepreneurship Research, Boston: Kluwer Academic Publishers, 55-79.

Acs, Z. J. and D. B. Audretsch, 1990, Innovation and Small Firms, Cambridge: MIT Press.

Audretsch, D. B., M. A. Carree, A. J. van Stel and A. R. Thurik 2005. 'Does Entrepreneurship Reduce Unemployment?', Centre for Economic Policy Research Discussion Paper DP5057, London.

Audretsch, D. B. and M. P. Feldman, 1996, 'R\&D Spill-overs and the Geography of Innovation and Production', American Economic Review 86, 630-640.

Audretsch, D. B. and M. Fritsch, 1996, 'Creative Destruction: Turbulence and Economic Growth in Germany', in E. Helmstädter and M. Perlman (eds.), Behavioral Norms, Technological Progress and Economic Dynamics: Studies in Schumpeterian Economics, Ann Arbor: University of Michigan Press, 137-150.

Audretsch, D. B. and M. Fritsch, 2002, 'Growth Regimes over Time and Space', Regional Studies 36, 113-124.

Audretsch, D. B. and M. Keilbach, 2004, 'Entrepreneurship Capital and Economic Performance', Regional Studies 38, 949-959.

Audretsch, D. B. and P. E. Stephan, 1996, 'Company-Scientist Locational Links: The Case of Biotechnology', American Economic Review 86, 641-652.

Audretsch, D. B. and A. R. Thurik, 2003, 'Entrepreneurship, Industry Evolution and Economic Growth', in R. Koppl. (ed.), Austrian Economics and Entrepreneurial Studies: Advances in Austrian Economics, 6, Oxford: Elsevier Science Ltd, 39-56.

Audretsch, D. B. and A. R. Thurik, 2001, 'What's New about the New Economy? Sources of Growth in the Managed and Entrepreneurial Economies', Industrial and Corporate Change 10, 267-315.

de Backer, K. and L. Sleuwaegen, 2003, 'Does Foreign Direct Investment Crowd Out Domestic Entrepreneurship?', Review of Industrial Organization 22, 67-84. 
Beck, Th., A. Demirguc-Kunt and R. Levine, 2005, 'SMEs, Growth, and Poverty: Cross-country Evidence', Journal of Economic Growth 10, 199-229.

Bartelsman, E., S. Scarpetta and F. Schivardi, 2003, 'Comparative Analysis of Firm Demographics and Survival: Micro-level Evidence for the OECD Countries', OECD Economics Department Working Papers No. 348, Paris: OECD.

Carree, M. A., 2002, 'Industrial Restructuring and Economic Growth', Small Business Economics 18, 243-255.

Carree, M. A. and A. R. Thurik, 2003, 'The Impact of Entrepreneurship on Economic Growth', in Z. J. Acs and D. B. Audretsch (eds.), Handbook of Entrepreneurship Research, Boston/Dordrecht: Kluwer Academic Publishers, 437-471.

Carree, M. A. and A. R. Thurik, 1999, 'Industrial Structure and Economic Growth', in D. B. Audretsch and A. R. Thurik (eds.), Innovation, Industry Evolution, and Employment, Cambridge: Cambridge University Press, 86-110.

Carree, M. A, A. J. van Stel, A. R. Thurik and A. R. M. Wennekers, 2002, 'Economic Development and Business Ownership: An Analysis Using Data of 23 OECD Countries in the Period 1976-1996', Small Business Economics 19, 271290.

Eliasson, G., 1995, 'Economic Growth Through Competitive Selection', paper presented at the 22nd annual EARIE Conference, Juan les Pins, 3-6 September 1995.

European Commission, 1999, Action Plan to Promote Entrepreneurship and Competitiveness, Luxembourg: Office for Official Publications of the European Communities, also at http://europa.eu.int/comm/enterprise/enterprise_policy/best/doc/actionplan_en.pdf.

European Commission, 2003, European Competitiveness Report 2003, Brussels: Commission staff working document, also at http://europa.eu.int/comm/enterprise/enterprise_policy/com petitiveness/doc/cr2003_en_12112003.pdf.

European Commission, 2004, Action Plan: the European Agenda for Entrepreneurship, Brussels: Commission of the European Communities, also at http://europa.eu.int/comm/ enterprise/entrepreneurship/action_plan.htm.

Evans, D. S., 1987, 'The Relationship Between Firm Growth, Size and Age: Estimates for 100 Manufacturing Industries', Journal of Industrial Economics 35, 567-581.

Foelster, S., 2000, 'Do Entrepreneurs Create Jobs?', Small Business Economics 14, 137-148.

Fritsch, M., 1996, 'Turbulence and Growth in West Germany: A Comparison of Evidence from Regions and Industries', Review of Industrial Organisation 11, 231-251.

Fritsch, M. and P. Mueller, 2004, 'The Effects of New Business Formation on Regional Development over Time', Regional Studies 38, 961-975.

Fritsch, M., 2007, 'How Does New Business Formation Affect Regional Development? Theory, Empirical Evidence and Research Questions', Small Business Economics (this issue).

Geroski, P. A., 1989, 'Entry, Innovation, and Productivity Growth', Review of Economics and Statistics 71, 572-578.
Glaeser, E. L., H. D. Kallal, J. A. Scheinkman and A. Shleifer, 1992, 'Growth in Cities', Journal of Political Economy 100, $1126-1152$.

Granger, C. W. J., 1969, 'Investigating Causal Relations by Econometric Models and Cross-spectral Methods', Econometrica 37, 424-438.

Hsiao, C., 2003, Analysis of Panel Data, Cambridge: Cambridge University Press.

Johnson, P., 2005, 'Targeting Firm Births and Economic Regeneration in a Lagging Region', Small Business Economics 24, 451-464.

Kirchhoff, B. A., 1994, Entrepreneurship and Dynamic Capitalism, Westport: Praeger.

Lay, T. J., 2003, 'The Determinants of and Interaction Between Entry and Exit in Taiwan's Manufacturing', Small Business Economics 20, 319-334.

Mueller, P., A. J. van Stel and D. J. Storey, 2007, 'The Effects of New Firm Formation on Regional Development over Time: the Case of Great Britain', Small Business Economics (this issue).

Nickell, S. J., 1996, 'Competition and Corporate Performance', Journal of Political Economy 104, 724-746.

Nickell, S., P. Nicolitsas and N. Dryden, 1997, 'What Makes Firms Perform Well?', European Economic Review 41, 783796.

Reynolds, P. D., 1999, 'Creative Destruction: Source or Symptom of Economic Growth?', in Z. J. Acs, B. Carlsson and Karlsson Ch. (eds.), Entrepreneurship, Small and Medium-sized Enterprises and the Macroeconomy, Cambridge: Cambridge University Press, 97-136.

Robbins, D. K., L. J. Pantuosco, D. F. Parker and B. K. Fuller, 2000, 'An Empirical Assessment of the Contribution of Small Business Employment to U.S. State Economic Performance'. Small Business Economics 15, 293-302.

van Stel, A. J., 2005, 'COMPENDIA: Harmonizing Business Ownership Data across Countries and over Time', International Entrepreneurship and Management Journal 1, 105-123.

van Stel, A. J., M. A. Carree and A. R. Thurik, 2005, 'The Effect of Entrepreneurial Activity on National Economic Growth', Small Business Economics 24, 311-321.

van Stel, A. J. and D. J. Storey, 2004, 'The Link between Firm Births and Job Creation: Is There a Upas Tree Effect?', Regional Studies 38, 893-909.

van Stel A. J. and K. Suddle 2007. 'The Impact of New Firm Formation on Regional Development in the Netherlands', Small Business Economics (this issue).

Stevenson, H. H. and D. E. Gumpert, 1991, 'The Heart of Entrepreneurship', in W. A. Sahlman and H. H. Stevenson (eds.), The Entrepreneurial Venture, Boston: McGraw-Hill, .

Storey, D. J. and P. Wynarczyk, 1996, 'The Survival and Non Survival of Micro Firms in the UK', Review of Industrial Organization 11, 211-229.

Taymaz, E., 2005, 'Are Small Firms Really Less Productive?', Small Business Economics 25, 429-445.

Wennekers, A. R. M. and A. R. Thurik, 1999, 'Linking Entrepreneurship and Economic Growth', Small Business Economics 13, 27-55. 